Citation: Ruhlusaraç, M., \& Çalışkan, F., A Mathematical Model For Dynamic Project Scheduling Problem And Reactive Scheduling Implementation, BMIJ, (2020), 8(4): 83-97 doi: http://dx.doi.org/10.15295/bmij.v8i4.1708

\title{
A MATHEMATICAL MODEL FOR DYNAMIC PROJECT SCHEDULING PROBLEM AND REACTIVE SCHEDULING IMPLEMENTATION 1
}

Murat RUHLUSARAÇ 2

Filiz ÇALIŞKAN ${ }^{3}$

\author{
Received Date (Başvuru Tarihi): \\ Accepted Date (Kabul Tarihi): \\ Published Date (Yayın Tarihi):
}

$23 / 02 / 2020$

$24 / 09 / 2020$

$10 / 12 / 2020$

$\underline{\text { In the article, the first author is in the role of Corresponding Author. }}$

\section{ABSTRACT}

Keywords:

Project Scheduling,

Dynamic Project,

Reactive Schedule,

Mathematical Model

JEL Codes:

M11, C61, O22
In today's real-life implementations, projects are executed under uncertainty in a dynamic environment. In addition to resource constraints, the baseline schedule is affected due to the unpredictability of the dynamic environment. Uncertainty-based dynamic events experienced during project execution may change the baseline schedule partially or substantially and require projects' rescheduling. In this study, a mixed-integer linear programming model is proposed for the dynamic resource-constrained project scheduling problem. Three dynamic situation scenarios are solved with the proposed model, including machine breakdown, worker sickness, and electricity power cut. Finally, generated reactive schedules are completed later than the baseline schedule.

\section{DİNAMIKK PROJE ÇİZELGELEME PROBLEMİ İÇINN MATEMATIKKSEL BİR MODEL VE REAKTIF ÇIZELGELEME UYGULAMASI}

$\ddot{O Z Z}$

Anahtar Kelimeler:

Proje Çizelgeleme,

Dinamik Proje,

Reaktif Çizelge,

Matematiksel Model

JEL Kodlarn:

M11, C61, O22
Günümüz gerçek hayat uygulamalarnnda projeler belirsizlik altında dinamik bir ortamda yürütülmektedir. Kaynak kısıtlannın yanı sıra dinamik ortamdaki öngörülemezlik nedeniyle de temel çizelge etkilenmektedir. Proje yürütülmesi sırasında yaşanan belirsizlik temelli dinamik olaylar temel çizelgenin kısmen veya büyük ölçüde değişmesini ve projelerin yeniden çizelgelenmesini gerektirebilmektedir. Bu çalışmada, dinamik kaynak kısıtl proje çizelgeleme problemi için bir karma tamsayıl doğrusal programlama modeli önerilmiştir. Önerilen modelle, makine arızalanması, iş̧ hastalanması ve elektrik kesintisi içeren ü̧̈ dinamik durum senaryosu çözülmüştür. Sonuç olarak, oluşturulan reaktif çizelgeler temel çizelgeye göre daha geç tamamlanmıştır.

\footnotetext{
${ }^{1}$ This article is an extended and improved version of the paper published in the proceedings of The 19th International Business Congress hosted by Erciyes University.

${ }^{2}$ Dr., Erciyes University, FEAS, Business, mruhlusarac@erciyes.edu.tr,

${ }^{3}$ Prof. Dr., Erciyes University, FEAS, Business, caliskan@erciyes.edu.tr

https://orcid.org/0000-0003-1092-8331

https://orcid.org/0000-0002-7079-7559
}

Business \& Management Studies: An International Journal Vol.:8 Issue:4 Year:2020, 83-97

Bu makale, araştırma ve yayın etiğine uygun hazırlanmış ve tithenticate intihal taramasından geçirilmiştir. 


\section{INTRODUCTION}

A project is a sequence of actions related to the start and end events. The project is aimed to be completed before a specific time or in time, not to exceed the budget, and to have certain features desired by the customer (Krajewski; Ritzman, Malhotra, 2010: 54). Dynamic projects initially contain a high degree of uncertainty and uncertainties throughout the schedule (Collyer and Warren, 2009: 356).

With the project scheduling, detailed time and resource use plans are made that indicate when the project and the activities completed and how the resources assigned to the activities (Hazır, Eryılmaz, and Hafızoğlu, 2014: 7). Dynamic scheduling, also known as online scheduling, involves real-time disruptions. The process of changing the current schedule to minimize the negatory effects of these disruptions by analyzing the current situation and minimizing possible interruptions is called dynamic project scheduling. The dynamic project scheduling is classified into four groups. (Leusin, Frazzon, Uriona Maldonado, Kück and Freitag, 2018: 5):

1. Completely Reactive Scheduling: In this method, real-time scheduling is done without generating a baseline schedule.

2. Predictive Reactive Scheduling: In this method, the baseline schedule is generated first and then rescheduling in response to real-time disruptions.

3. Predictive Reactive Robust Scheduling: It is the method where the baseline schedule is generated first and then rescheduled when the effect of deterioration in performance criteria is significant.

4. Robust Proactive Scheduling: It is the method in which the effect of disruptions in the production process is predicted, and the baseline schedule is developed accordingly.

Dealing with uncertain situations and real-time disruptions encountered in the project scheduling environment and producing solutions are significant for every project manager (Van de Vonder, Ballestín, Demeulemeester and Herroelen, 2007, p. 11). There are some difficulties with uncertainty. These (Collyer and Warren, 2009: 357): 
- Product life is short.

- The rate of use of new materials is high.

- Finding and managing a skilled workforce is challenging.

- It is necessary to understand the customer very well.

- Needs and objectives are changing rapidly.

- Planning is more complicated.

- Employees' morale and motivation are affected.

- Other projects with which it interacts are also changing.

The uncertainty can be internal or external. Internal ones can be controlled highly by the company and directly related to the project. Hazir and Ulusoy (2019) have categorized uncertainties into three groups; organizational, related to the project's scope, or available resources. Uncertainties in the project's extent may arise from changes in activity periods, resource use, needs, or quality. However, the company's external uncertainties cannot be controlled and caused by factors outside of the project. External ones can be about market, technology, sociopolitical, environmental, and logistics (Hazir and Ulusoy, 2019: 4).

The scheduling systems in practice must respond to these uncertainties in realtime within an acceptable time. When and how to react to real-time events have been identified as two significant policies. First, we decide when the system to be revised. There are three alternatives for this. Revision can be done in a periodic, event-based, or mixed-method. While the schedules are generated at regular intervals with the periodic policy, revisions are made with the event-based policy when uncertainty arises. With the mixed policy, the system can be revised both at regular intervals and when uncertainty arises. It is also important how to react after deciding when to respond to uncertainty. In case of system breakdown, doing nothing while rescheduling or a schedule repair is an option (Sabuncuoglu and Bayiz, 2000). 


\section{CONCEPTUAL FRAMEWORK}

Van de Vonder (2006) examined the impact of uncertainty on project scheduling. He proposed a proactive method for generating baseline schedules. As the proactive method seems insufficient, he developed reactive methods that define how to behave in case of interruptions in the schedule. He applied his suggested approaches in a real-life project in the Belgian construction industry.

Van de Vonder, Ballestín, Demeulemeester, and Herroelen (2007) proposed heuristic reactive scheduling methods to repair resource-constrained project baseline schedules damaged by multiple disruptions during project execution. They aimed to minimize the deviations between the baseline schedule and the actual schedule.

Van de Vonder, Demeulemeester, and Herroelen (2007) have addressed a multiobjective problem that maximizes both schedule stationarity and the probability of completing projects in time. They proposed a reactive resource-constrained project scheduling method foreseen for the problem and tested the method's performance.

Da Silva, Ochi, and Santos (2008) developed a new example for the dynamic resource-constrained project scheduling problem. They proposed a genetic algorithm for the problem and demonstrated the competitive performance of new crossover operators.

Van de Vonder, Demeulemeester, and Herroelen (2008) have developed new multiple algorithms that include buffer times in a given schedule to comply with deadlines in the project. They have proposed various heuristics and metaheuristics for these buffers. They analyzed the performance of all algorithms with simulation.

André Renato Villela Da Silva and Ochi (2010) studied the dynamic resourceconstrained project scheduling problem (DRCPSP) that includes an uncommon resource type. They developed a new mathematical model for DRCPSP and proposed two-hybrid heuristics together with the genetic algorithm.

Çapa (2013) has addressed a dynamic resource-constrained project scheduling problem that has been faced by a household goods company in Turkey. She developed a three-step method for this problem. In the first phase, she developed models; in the 
second phase, she proposed a genetic algorithm. In the third phase, she presented a reactive method to revise the baseline schedule when unexpected situations occurred.

Ruhlusaraç and Çalışkan (2018) discussed the multi-mode resource-constrained multi-project scheduling problem. They based this problem on a just-in-time production philosophy and minimized weighted earliness and tardiness costs. They solved the problem of four activities with three projects and two modes in GAMS optimization software.

Song, Xi, Kang, and Zhang (2018) proposed a simulation model for resourceconstrained multi-project scheduling problem under uncertainty. Their goal has been to develop robust schedules for multiple complex projects and make information easy to access. They have designed proactive and reactive scheduling algorithms to solve unforeseen interruptions and increase the robustness of solutions in the simulation system.

Adamu, Akinwumi, and Okagbue (2019) proposed a model called the hybrid resource-constrained project scheduling problem to solve the project's delays. They validated their solution method using two project examples.

Joo, Chua, Cai, and Chua (2019) addressed a reactive multi-mode resourceconstrained project scheduling problem with limited construction material storage space. They proposed a coordination-based reactive scheduling method for the problem. They argued that the method they proposed was acceptable for businesses with limited raw material space and work-to-order.

Wang, Ge, Li, and Su (2019) described the proactive and reactive multiple scheduling problem. To create the baseline schedule, they first used the proactive multi-scheduling sub-model and then generated a reactive scheduling sub-model when activity was interrupted. They developed a genetic simulated annealing algorithm with the models they proposed to produce alternative schedules.

Ben Issa, Patterson, and Tu (2020) presented a generalized resource-constrained multi-project problem with ABD activity assumptions (RCMPSPABD). They developed heuristics for solving the RCMPSPABD. Experimental results have shown that significant reductions in the entire project's makespan have been possible while the 
resources used in other projects are released. To define the combined problem, they also presented a mixed integer-linear program (MILP) formulation. Their problem has a wide range of applications such as project type production and construction environment.

Hauder, Beham, Raggl, et al. (2020) introduced a new resource-constrained project scheduling problem (RCPSP) that has both decisions (time and activity flexibility). They presented two new alternative maximization objectives: time balance and resource balance, and the minimization of makespan. They proposed new mixed integer and constraint programming models for the integrated flexible project scheduling problem. Then, they solved their developed new problem and existing benchmark instances on flexible RCPSP. Finally, they stated that the proposed CP models have a wide application area.

Zaman, Elsayed, Sarker, et al. (2021) studied RCPSPs with uncertain activity durations. They proposed a simulation-based evolutionary algorithm including two operators based EAs, two heuristics for optimization, and a simulation method to deal with the uncertain durations. With the simulation approach, they generated the problem instances based on uncertainty. In the EA framework, they proposed a new plan descending the number of simulation runs. There was not be any discretization of the periods in their mathematical programming approach. They solved more than 1600 test problems and some industrial problems with 120 activities using the proposed approach. The results were quite acceptable in terms of quality and computational time.

\section{RESEARCH METHOD}

In the study, as a research method, firstly, a mixed-integer linear programming model was given for the resource-constrained project scheduling problem. Then, we presented a model proposal for rescheduling with the predictive reactive scheduling logic in case of various disruptions in the schedule by making adjustments to this static model. We obtained distinct solutions for a project example with this dynamic model, consisting of 6 activities for machine breakdown, worker sickness, and electricity power cut. 


\subsection{Resource-Constrained Project Scheduling Problem (RCPSP)}

The integer linear programming model for the resource-constrained project scheduling problem is as follows (Pritsker, 1968):

\section{Notations:}

T: Time set

$J:$ Activity set

R:Resource set

a: Subset of activity, element of the J set

$b$ : Subset of activity, element of the J set, $a<b$

$h$ : Subset of time set, element of the T set

\section{Parameters:}

$p_{j}$ : The processing time of activity $j$ (min.)

$q_{j r}$ : The amount required by activity $j$ from resource $r$ (pieces)

$Q_{r}$ :The available amount of resource $r$ (pieces)

\section{Variables:}

$X_{j t}: 1$ if activity $j$ completes at time $t, 0$ otherwise

$$
\begin{array}{lc}
\text { Min } \quad \sum_{t=1}^{T} t X_{J t} & \\
\text { s.t. } \sum_{t=1}^{T} X_{j t}=1 & \forall j \in J \\
\sum_{t=1}^{T} t X_{a t} \leq \sum_{t=1}^{T} t X_{b t}-p_{b} & \forall(a, b) \in J \\
\sum_{j=1}^{J} \sum_{h=t}^{t+p_{j}-1} q_{j r} X_{j h} \leq Q_{r} & \forall r \in R, \forall t \in T \\
X_{j t} \in\{0,1\}, \quad j=1, \ldots, J, & t=1, \ldots, T
\end{array}
$$

The objective function at number 1 minimizes the completion time of the last activity. At constraint number 2, we ensure that executing each activity only once. At constraint number 3 , priority relationships between activities a and $\mathrm{b}$ are provided. At 
constraint number 4, we provide that not exceed the number of available resources. At constraint number 5 , we give information about the $X$ variable, $j$, and $t$ set.

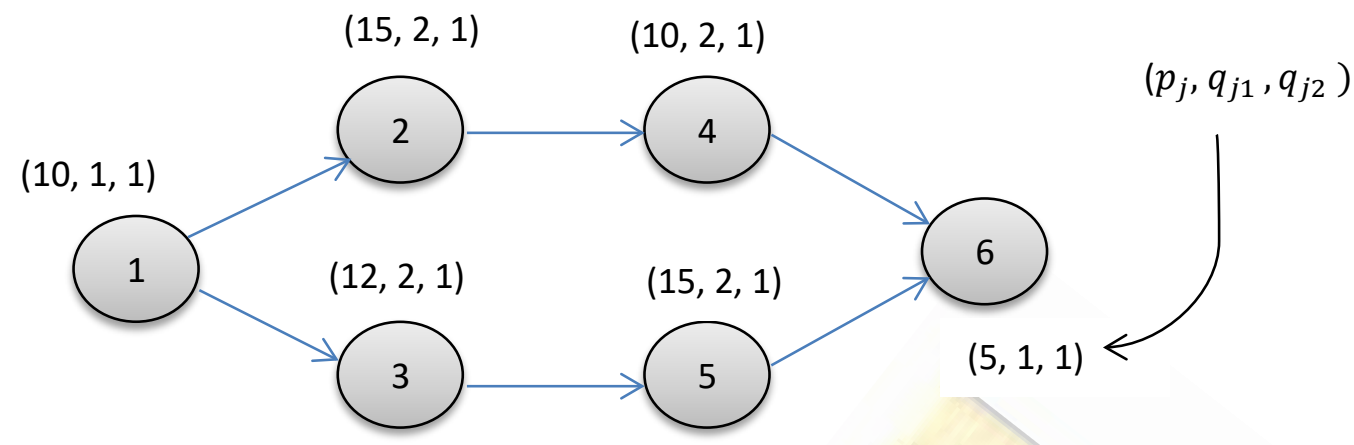

Figure 1. Network Model of The Sample

The network model of a project consisting of 6 activities is given in Figure 1. In this activity on node (AON) model, the nodes' information is the processing time of the activity and the usage amounts from the first resource and the second resource. The first resource is the worker, and we have two workers. The second is the cutting machine, and we have one cutting machine.

\subsection{Dynamic Resource-Constrained Project Scheduling Problem (DRCPSP)}

The integer linear programming model suggested for dynamic resourceconstrained project scheduling problem is as follows:

\section{$\underline{\text { Parameters: }}$}

$p_{j}^{*}$ : Process time of activity $j$ in the reactive schedule (min.)

$q_{j r}^{*}:$ The amount required by activity $j$ from resource $r$ in the reactive schedule (pieces)

$Q_{r}^{*}:$ The available amount of resource $r$ in the reactive schedule (pieces)

Variables:

$X_{j t}^{*}: 1$ if activity $j$ completes at time $t$ in the reactive schedule, 0 otherwise

$$
\begin{array}{lll}
\text { Min } & \left|\sum_{t=1}^{T} t X_{J t}-\sum_{t=1}^{T^{*}} t X_{J t}^{*}\right| & \\
\text { s.t. } & \sum_{t=1}^{T} X_{J t}^{*}=1 & \forall j \in J^{*}
\end{array}
$$




$$
\begin{array}{lc}
\sum_{t=1}^{T^{*}} t X_{a t}^{*} \leq \sum_{t=1}^{T^{*}} t X_{b t}^{*}-p_{b}^{*} & \forall(a, b) \in J^{*} \\
\sum_{j=1}^{J^{*}} \sum_{h=t}^{t+p_{j}-1} q_{j r}^{*} X_{j h}^{*} \leq Q_{r}^{*} & \forall r \in R^{*}, \forall t \in T^{*} \\
X_{J t}^{*} \in\{0,1\}, & t=1, \ldots, T^{*}
\end{array}
$$

The objective function in number 1 minimizes the absolute difference between the completion time of the last activity in the baseline schedule and the end activity's completion time in the reactive schedule. At constraint number 2, we ensure that each activity is scheduled only once in the reactive schedule. At constraint number 3, priority relationships between activities $\mathrm{a}$ and $\mathrm{b}$ are provided in the reactive schedule. At constraint number 4, we ensure that not exceed the number of available resources in the reactive schedule. At constraint number 5, we give information about the variable $\mathrm{X}_{\mathrm{Jt}}^{*}$ and the set $\mathrm{j}$, and $\mathrm{t}$.

In cases of disruption in the baseline schedule, we will reschedule using the proposed dynamic model to generate reactive schedules. Thus, firstly, we produce sample scenarios related to disruption situations, then rescheduling will be made using a dynamic model in response to these situations.

\subsubsection{Scenario 1: Machine Breakdown}

Suppose one machine breaks down on the $11^{\text {th }}$ minute and will be back in service on the $30^{\text {th }}$ minute. Accordingly, the baseline schedule created will be interrupted on the $11^{\text {th }}$ minute, and the reactive schedule will need to be obtained by rescheduling with updated data.

\subsubsection{Scenario 2: Worker Sickness}

Suppose one worker gets sick on the $26^{\text {th }}$ minute, and his treatment will be over on the $40^{\text {th }}$ minute. Accordingly, the baseline schedule created will be interrupted on the $26^{\text {th }}$ minute, and a reactive schedule will need to be obtained by rescheduling with updated data. 


\subsubsection{Scenario 3: Electricity Power Cut}

Suppose the electricity is cut off unplanned on the $23^{\text {rd }}$ minute, and we learn that it will come back on the $40^{\text {th }}$ minute according to the information we have obtained. Accordingly, production will suddenly stop on the $23^{\text {rd }}$ minute, and the baseline schedule will be interrupted. According to the new plan, a reactive schedule will be created to continue production from the $40^{\text {th }}$ minute.

\section{RESULTS AND DISCUSSION}

We coded the sample problem whose network model was given above and solved it in the GAMS program. Then, we gave Table 1 for the GAMS solution results. According to the solution, we obtained 68 minutes that the project completion time for the sample problem.

Table 1. The X Variable GAMS Solution Results

\begin{tabular}{|c|c|c|c|c|c|c|}
\hline $\boldsymbol{X}_{\mathbf{j}}$ & $\mathbf{X}_{\mathbf{1}}$ & $\mathbf{X}_{\mathbf{2}}$ & $\mathbf{X}_{\mathbf{3}}$ & $\boldsymbol{X}_{\mathbf{4}}$ & $\boldsymbol{X}_{\mathbf{5}}$ & $\boldsymbol{X}_{\mathbf{6}}$ \\
\hline $\boldsymbol{t}$ results & 11 & 38 & 23 & 63 & 53 & 68 \\
\hline
\end{tabular}

The Gantt chart of the sample shows the solution in Figure 2. When Figure 2 is examined, we can see that activities are carried out one after the other, but there are no activities executed in parallel.

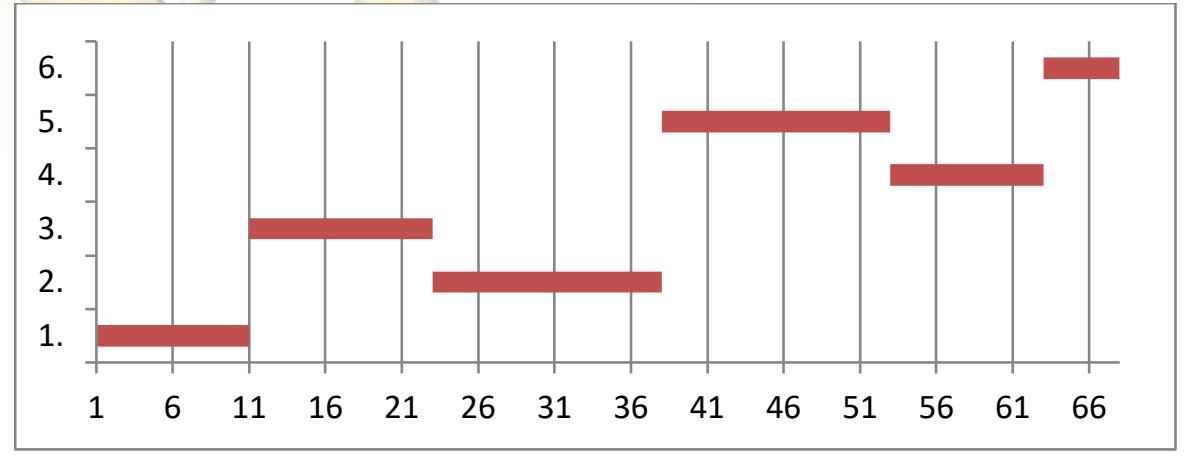

Figure 2. The Gantt Chart of Sample

For all scenarios, the solutions were obtained by coded the DRCPSP mathematical model in the GAMS program. According to the solution results of scenario 1 , the project completion time was 87 minutes. The objective function value 
was 19 since there are absolute differences between the baseline schedule and the reactive schedule completion time. The activities' completion times were at 11, 45, 57, $67,82,87^{\text {th }}$ minutes, respectively. The Gantt chart of scenario 1 shows the solution in Figure 3. When Figure 3 is examined, we can see that activities not be executed due to the machine breakdown in 11-30 minutes.

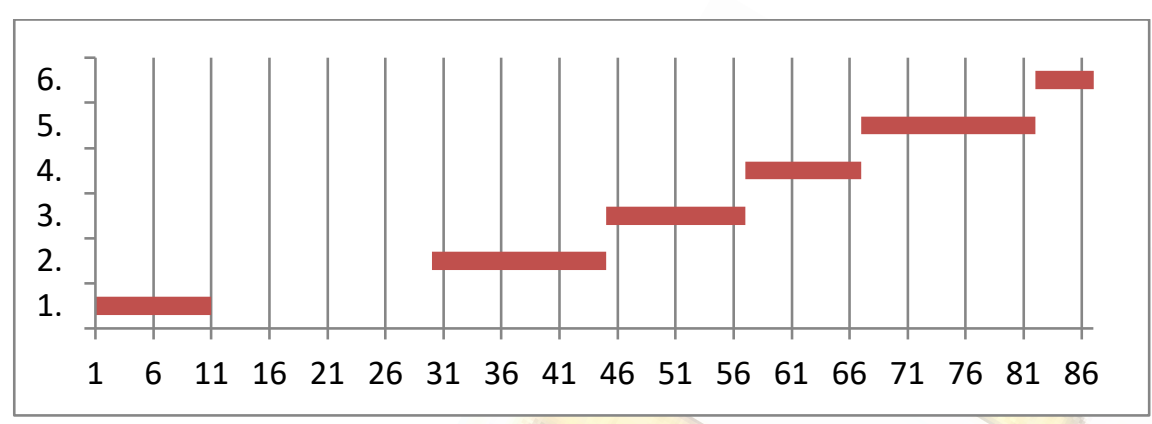

Figure 3. The Gantt Chart of Scenario 1

According to the solution results of scenario 2, the project completion time was 82 minutes. The objective function value was 14 because there are absolute differences between the baseline schedule and the reactive schedule completion time. The activities' completion times were at $11,26,52,77,67,82^{\text {nd }}$ minutes, respectively. In Figure 4, there is the Gantt chart of scenario 2 showing the solution. When Figure 4 is examined, we can see that activities not be carried out between 26-40 minutes due to 1 worker getting sick.

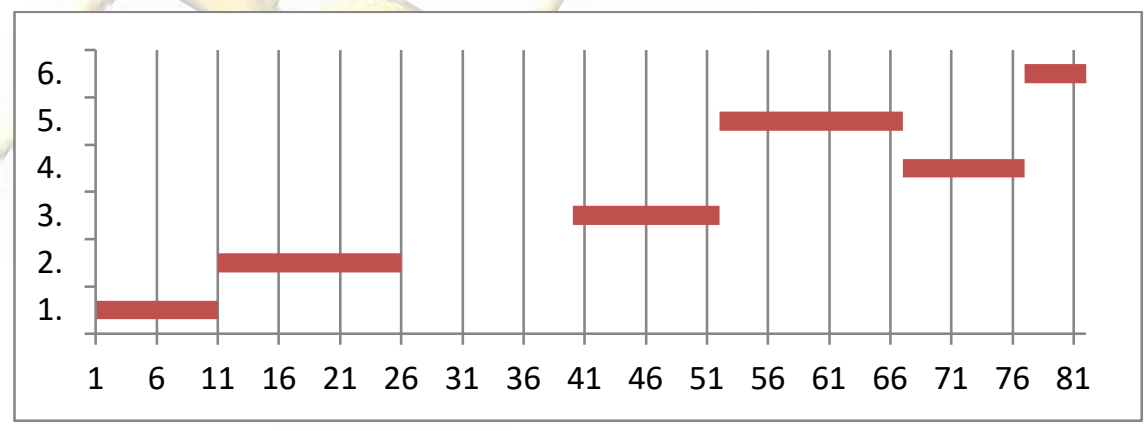

Figure 4. The Gantt Chart of Scenario 2

According to the solution of scenario 3, the project completion time was 85 minutes. The objective function value was 17 because there are absolute differences between the baseline schedule and the reactive schedule completion time. The activities' completion times were at $11,55,23,65,80,85^{\text {th }}$ minutes, respectively. In 
Figure 5, there is the Gantt chart of scenario 3 showing the solution. When Figure 5 is examined, we can see that activities not be carried out between 23-40 minutes due to an electricity power cut.

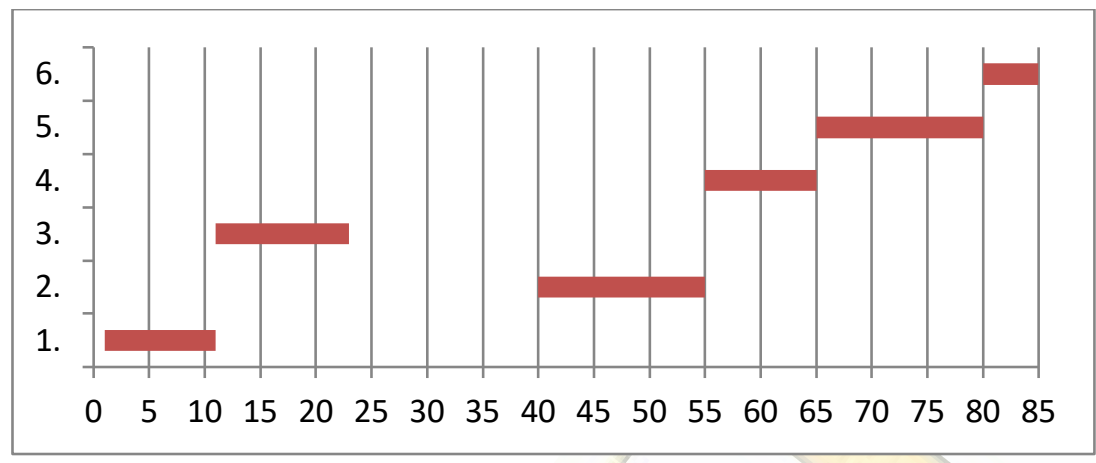

Figure 5. The Gantt Chart of Scenario 3

\section{CONCLUSION AND RECOMMENDATIONS}

Nowadays, it is inevitable to encounter some dynamic situations because projects are carried out under uncertainty. Priority changes between projects, differences in the processing times of activities, problems in raw material supply, workers quarantined due to the pandemic, suddenly broken machines, changes in customer requests are among the most common current uncertainties. When such dynamic situations are encountered while the projects are being executed, it may be necessary to adapt to the environment immediately and reschedule.

This paper proposed a new mixed-integer linear programming model for the dynamic project scheduling problem and coded this model in the GAMS optimization program. We calculated the absolute difference between the baseline schedule objective function value and the reactive schedules objective function values for the three scenarios with the model. In the sample problem and dynamic case scenarios, we observed that the completion times of the generated reactive schedules finished later than the baseline schedule.

According to the sample's solution result, the project completion time was 68 minutes. This time was found at 87 minutes in scenario 1, 82 minutes in scenario 2 , and 85 minutes in scenario 3. Figure 6 shows the shape of these completion times. Accordingly, when each dynamic situation occurred and the baseline schedule was 
disrupted, the reactive schedule completion times were greater than the baseline schedule. So, every disruption situation delayed activities. Thus, scenario 1 deviated from the baseline schedule by 19 minutes, scenario 2 by 14 minutes, and scenario 3 by 17 minutes.

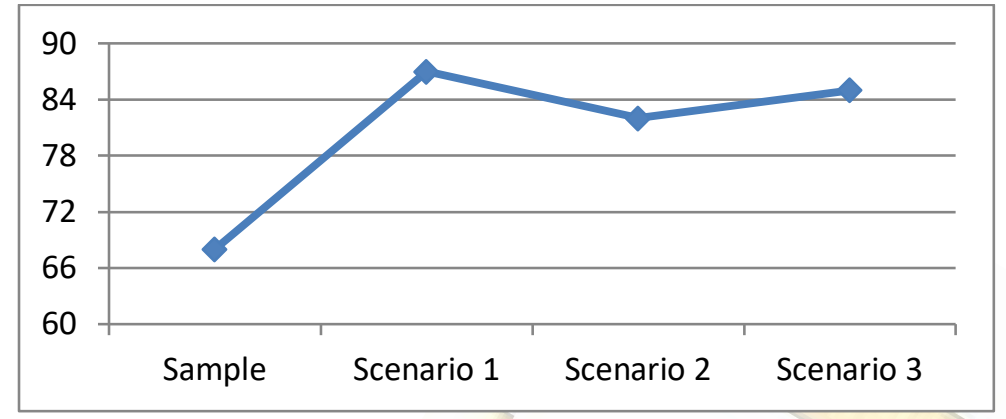

Figure 6. Completion Times of All Problems

For future studies, it would be appropriate for researchers to turn to larger reallife problems or test problems to compare their methods' performance. 


\section{REFERENCES}

Adamu, P. I., Akinwumi, I. I., \& Okagbue, H. I. (2019). Reactive project scheduling: minimizing delays in the completion times of projects. Asian Journal of Civil Engineering, 20, 1189-1202.

Ben Issa, S., Patterson, R.A., \& Tu, Y. (2020). Solving resource-constrained multiproject environment under different activity assumptions, International Journal of Production Economics, 107936, 1-41.

Çapa, C. (2013). A Three-Phase Approach For Robust Project Scheduling: An Application For R\&D Project Scheduling, Master Thesis, Sabanci University, 1-209.

Collyer, S., \& Warren, C. M. J. (2009). Project management approaches for dynamic environments. International Journal of Project Management, 27(4), 355-364.

Da Silva, André Renato Villela, \& Ochi, L. S. (2010). Hybrid heuristics for dynamic resource-constrained project scheduling problem. Lecture Notes in Computer Science (Including Subseries Lecture Notes in Artificial Intelligence and Lecture Notes in Bioinformatics), 6373 LNCS, 73-87.

Da Silva, Andre Renato Villela, Ochi, L. S., \& Santos, H. G. (2008). New effective algorithm for Dynamic Resource Constrained Project Scheduling Problem, (June), 1-5.

Hauder V.A., Beham A., Raggl S., Parragh S.N., \& Affenzeller M. (2020) Resource-constrained multiproject scheduling with activity and time flexibility. Computers \& Industrial Engineering, 150, 106857, $1-42$.

Hazir, O., \& Ulusoy, G. (2019). A Classification And Review Of Approaches And Methods For Modeling Uncertainty In Projects. International Journal of Production Economics, 1-52.

Hazır, Ö., Eryılmaz, U., \& Hafızoğlu, M. (2014). Proje Yönetimi: Analitik Yaklaşımlar. PMI TR.

Joo, B. J., Chua, T. J., Cai, T. X., \& Chua, P. C. (2019). Coordination-based reactive resource-constrained project scheduling. Procedia CIRP, 81, 51-56.

Krajewski, L. J., Ritzman, L. P., \& Malhotra, M. K. (2010). Operations Management Processes and Supply Chains, Pearson Prentice Hall, 1-640.

Leusin, M., Frazzon, E., Uriona Maldonado, M., Kück, M., \& Freitag, M. (2018). Solving the Job-Shop Scheduling Problem in the Industry 4.0 Era. Technologies, 6(4), 107.

Pritsker, A. Alan B. and Lawrence J. Watters. (1968). A Zero-One Programming Approach to Scheduling with Limited Resources. Santa Monica, CA: RAND Corporation, 1-59.

Ruhlusaraç, M., \& Çalışkan, F. (2018). Ağırlıklı Erken ve Geç Bitirme Maliyetli Çok Modlu Kaynak Kısıtlı Çoklu Proje Çizelgeleme Problemi. International Science and Technology Conference, July 18-20, 2018 Paris,France, 60-64.

Sabuncuoglu, I., \& Bayiz, M. (2000). Analysis of reactive scheduling problems in a job shop 
environment. European Journal of Operational Research, 126(3), 567-586.

Song, W., Xi, H., Kang, D., \& Zhang, J. (2018). An Agent-based Simulation System for Multi-Project Scheduling under Uncertainty. Simulation Modelling Practice and Theory, 86, 187-203.

Van de Vonder, S. (2006). Proactive-reactive procedures for robust project scheduling. Applied Economics, Doctoral Dissertation, (247), 1-219.

Van de Vonder, S., Ballestín, F., Demeulemeester, E., \& Herroelen, W. (2007). Heuristic procedures for reactive project scheduling. Computers and Industrial Engineering, 52(1), 11-28.

Van de Vonder, S., Demeulemeester, E., \& Herroelen, W. (2008). Proactive heuristic procedures for robust project scheduling: An experimental analysis. European Journal of Operational Research, 189(3), 723-733.

Van De Vonder, S., Demeulemeester, E., \& Herroelen, W. (2007). A classification of predictive-reactive project scheduling procedures. Journal of Scheduling, 10(3), 195-207.

Wang, W., Ge, X., Li, L., \& Su, J. (2019). Proactive and Reactive Multi-Project Scheduling in Uncertain Environment. IEEE Access, 7, 88986-88997. 